\title{
Antecedents of Job Satisfaction and the Influence on Turnover Intention
}

\author{
Ceacilia Srimindarti ${ }^{\bowtie}$, Rachmawati Meita Oktaviani, Pancawati Hardiningsih \\ Faculty of Economics and Business, Stikubank University, Semarang, Indonesia
}

\section{Info Article}

History Article:

Received July 2017

Approved August 2017

Published September 2017

\section{Keywords:}

Leadership Style; Organizational

Commitment; Job Satisfaction;

Turnover Intention.

\begin{abstract}
This study aimed to examine the effect of the antecedent of job satisfaction on job satisfaction, the influence of leadership style, organizational commitment and job satisfaction on turnover intention and whether job satisfaction was able to mediate the relation of antecedent of job satisfaction on turnover intention. The respondents in this study were employees at consulting firms in Semarang. The analysis instrument in this research was the multiple regression. The study showed that leadership style and organizational commitment had positive influence on job satisfaction. The other result of this study showed that leadership style, organizational commitment and job satisfaction had negative influence on turnover intention. With the proven fact of the influence of leadership style, organizational commitment and job satisfaction on turnover intention, the managers of consulting firms, therefore, should use leadership style that fit with employees, should try to increase the organization's commitment to employees so they knew that they were a part of the organization and to maintain their membership in the organization and should improve employee satisfaction in order to reduce the turnover intention among employees.
\end{abstract}

\section{Anteseden Kepuasan Kerja dan Pengaruhnya Terhadap Intensi Keluar}

\begin{abstract}
Abstrak
Penelitian ini bertujuan untuk menguji anteseden kepuasan kerja terhadap kepuasan kerja, pengaruh gaya kepemimpinan, komitmen organisasi dan kepuasan kerja terhadap intensi keluar, serta apakah kepuasan kerja mampu memediasi hubungan antara anteseden kepuasan kerja terhadap intensi keluar. Responden dalam penelitian ini adalah karyawan yang bekerja di kantor konsultan di Semarang. Alat analisis yang digunakan dalam penelitian ini adalah regresi berganda. Hasil penelitian menunjukkan bahwa gaya kepemimpinan dan komitmen organisasi berpengaruh positif terhadap kepuasan kerja. Hasil lain dari penelitian ini menunjukkan bahwa gaya kepemimpinan, komitmen organisasi dan kepuasan kerja berpengaruh negatif terhadap intensi keluar. dengan terbuktinya pengaruh gaya kepemimpinan, komitmen organisasi, dan kepuasan kerja terhadap intensi keluar, maka sebaiknya manajer kantor konsultan menggunakan gaya kepemimpinan yang cocok dengan karyawan, berusaha meningkatkan komitmen organisasi agar karyawan merasa menjadi bagian dari organisasi dan berusaha mempertahankan keanggotaan dalam organisasi, serta meningkatkan kepuasan karyawan agar dapat mengurangi intensi keluar karyawan.
\end{abstract}

JEL Classification: M5, M51

How to Cite: Srimindarti, C., Oktaviani, R. M \& Hardiningsih, P. 2017. Antecedents of Job Satisfaction and the Influence on Turnover Intention. Jurnal Dinamika Manajemen. 8 (2): 177-187. 


\section{INTRODUCTION}

In this era, everything has become more competitive. This condition requires the manager to manage all of its resources properly so that the organization can survive. Companies will find difficulty to maintain viability without the support of a loyal and skilled employees. Employees are invaluable resources for organizations including those of consultants' offices. Employees are the spearhead that could affect the survival of the organization. the consequence if employees are not able to perform at work in accordance with the organization's standards, the services to the clients became less optimal. the quality of consultant firm services to clients are affected by the employees.

One of the serious problems faced by the organization is the turnover intention. Turnover intention is individual's desire with full consciousness to leave the organization where these individuals work (Robbins \& Judge, 2013). The high percentage of employee turnover intention will be a problem to the organization. This condition causes complaints both from clients and managers because the works, should then, be performed by new employees are lack of experiences. The high turnover intention in the organization causes more potential costs to be incurred by the organization. The fee covers the training cost that has been invested in the employees and the recruiting and retraining cost (Zhang, 2016).

There are several factors that influence the turnover intention, but this study is limited to job satisfaction, leadership style and organizational commitment. One of the factors that may affect the turnover intention is job satisfaction. Job satisfaction is someone's feeling about his job whether positive or negative. Employee perceptions about whether they enjoy the job or not, is created from their experiences. If employees are satisfied with the various dimensions of the job they will not look for another job. It can be said the job satisfaction is strongly associated with the turnover intention. Several stu- dies examined the effects of job satisfaction to the turnover intention. The results showed that job satisfaction had negative effects to the turnover intention (Fitriany et al., 2011; Mahdi et al., 2012; Sutanto \& Gunawan, 2013; Saeed et al., 2014).

Another factor that may affect turnover intention from the organization is the leadership style. Leadership style is a way used by leaders in directing subordinates to achieve the organizational goals. One of the reason causing employees to leave and to look for another job is because they do not feel comfortable with the way authority is delivered.When the employees feel comfortable with the way the authority directing employees, they will retain their jobs. Several studies found that leadership style had negative effects to the turnover intention (Gul et al., 2012; Sartika, 2014; Amankwaa \& Tsede, 2015; Puni et al., 2016). Another study found leadership style had no effect to the turnover intention (Long et al., 2012; Gul et al., 2012).

The next factor that effect on turnover intention is the organizational commitment. Organizational commitment is the relative strength of individual identification in an organization and her or his involvement in a particular organization (Parker \& Kohlmeyer, 2005). If the employees have a strong relation to the organization, they will try to maintain membership in the workplace. A strong emotional attachment between the employee and the organization will reduce the employee's turnover intention. The results of previous studies found the organizational commitment had negative effects to the turnover intention (Fitriany et al., 2011; Joo \& Ready, 2012; Long et al., 2012; Mehrad \& Fallahi, 2014; Bateh \& Heyliger, 2014; Siddiqui \& Jamil, 2015; Srimindarti et al., 2015; Sun et al., 2016). But Yasmin and Marzuki (2015) found that organizational commitment had no effect on turnover intention.

There are many factors that can affect the employee job satisfaction level. The affecting factor to the job satisfaction can be derived from the individual and job characteristic (Bender et 
al., 2005). This study examined the influence of organizational variables such as leadership style and individual variables such as organizational commitment to the job satisfaction. The employee who feels more suitable against his authority's leadership style will increase job satisfaction, otherwise if the employee feels uncomfortable, authority's leadership style will lead to higher dissatisfaction with the job. Some studies found a leadership style had positive effect on job satisfaction (Joo \& Ready, 2012; Bateh \& Heyliger, 2014; Long et al., 2014; Mehrad \& Fallahi, 2014; Siddiqui \& Jamil, 2015; Sun et al., 2016).

Another factor that can influence job satisfaction is organizational commitment. Organizational commitment is a psychological construct where there is a relationship characteristics between the organization member with the organization and had implications for an individual's decision to continue its membership in the organization (Meyer \& Allen, 1991). If employees have a strong commitment to the organization, it is illustrated that the employees will be satisfied with the job, which will make the employees decide to continue their membership in the organization. Several studies found that an organizational commitment had positive effects on the job satisfaction (Anis et al., 2011; Adekola, 2012). The different results found that affective organizational commitment had no effect on job satisfaction (Gangai \& Agrawal, 2014).

Based on the description above and on the basis of the reviews of previous studies, there are several factors that influence the turnover intention. The high turnover intention in the organization causes more potential costs such as fee covers the training cost that has been invested in the employees and the recruiting and retraining cost. The motivation of this research is provided a solution for manager to decrease turnover intention. This study aimed to examine the influence of organizational variables such as leadership style and individual variables such as organizational commitment and job satisfaction on turnover intention. This study is ex- pected to give contribution to human resource science especially those associated with turnover intention.

\section{Hypothesis Development}

This research was conducted on the basis of the attribution theory that explains factors that causing a personal behavior. Attribution theory was used to explain the influence of job satisfaction, leadership style and organizational commitment on turnover intention. This theory explains how someone relates the causes of the behavior of others as well as himself. A person's motifs for doing certain actions can be sourced from internal (dispositional attributtions) and external or situational attributtions. The internal causes tend to be directed at individual behavioral aspects, something that already exists within oneself as a personal nature, self-perception, ability and motivation.

While external causes are more likely directed at the environment that affects a person's behavior, such as social conditions, social values and social perceptions. Based on this theory, the decision of an employee's actions to leave her/ his institution or to choose to retain jobs can be caused by individuals internal factors as well as environmental factors. Above explanation provides theoretical support to the notion that the employees' individual factors and organizational factors may influence the employees decision to leave the organization or keep their job. Such support is explained by looking at the root cause of an employee leaving their job or remain in the organization.

\section{The Influence of Job Satisfaction on Turnover Intention}

Robbins and Judge (2013), defines job satisfaction as positive feelings about a job, which is the impact or results of the job various aspects evaluation. Meanwhile, Wood et al. (1998) defines job satisfaction as the extent to positively or negatively individual feelings about their job, which is a person's emotional response to the task as well as the physical and social conditions in the workplace. Job satisfaction can be measu- 
red by using Job Descriptive Index (Robbins \& Judge, 2013).

Job satisfaction is one of the factors that may affect turnover intentions. Job satisfaction is defined as a positive feeling on the job, which is the impact or results of the work done using various aspects of evaluation (Robbins \& Judge, 2013). If the employee is satisfied with his job, he assesses their work more positively. This condition will decrease the turnover intentions. However, if the employee was not satisfied with his job, the opposite situation will occur and turnover intention will increase (Fitriany et al., 2011). Research conducted by Saeed et al. (2014) found that a job satisfaction had a negative effect on turnover intentions (Fitriany et al., 2011; Mahdi et al., 2012; Sutanto \& Gunawan, 2013; Khan \& Aleem, 2014)

Based on the description above and on the basis of a previous studies review, it can be concluded that job satisfaction, leadership style and organizational commitment influence the turnover intention. So the first Hypothesis in this study is:

H1: Job Satisfaction has negative effect on Turnover Intention.

\section{The Impact of Leadership Style on Turnover In- tention}

Leadership style is a way for an authority to influence others or subordinates such a way that the person is willing to do the authority's will to achieve organizational goals although personally it might displease. Consideration leadership style is a style that illustrates the close relationship between authority and employee, trust among them, kinship, appreciate to the employee's idea and the communication between authority and employee. Leaders who have a consideration style emphasize the importance of open communication with employee.

Leadership is an important factor in an organization, because by the good leadership organizational goals can be achieved. Leadership is the ability to influence a group to achieve a goal, which means either formally appointed by the company concerned and informally is not appointed by the company, but has the ability to influence others (Robbins \& Judge, 2013). There are different styles of leadership. Previous studies that examine the effect of leadership style on turnover intention found the results as follows: democrative leadership style has negative effect to the turnover intention. When the leaders appreciate each member of the organization style,characteristics and capabilities, the leader always involves the employee in decision making when facing problems. The employees feel appreciated so the turnover intentions will be low (Puni et al., 2016).

Another research by Long et al. (2012), found that a transformational and transactional leadership styles affect the turnover intention. The results of the study implies that when a leader has a transformational style, he has a capability to direct the employees on sensitivity training and organizational development and he is able to transform the organization's resources optimally in order to achieve the organization's objectives in accordance with the targets set.

Transactional leadership style encourages employee to work by providing the resources and rewards in exchange for motivation, productivity and achievement of the task. Amankwaa and Tsede (2015), found that transformational leadership style has a negative effect to the turnover intention. This means that if a leader can oversee and direct employees to achieve objectives effectively, it will decrease the turnover intention. Based on the review studies and explanations described earlier, the second hypotheses proposed in this study is:

H2: Leadership Style has negative effect on Turnover Intention.

\section{The Effect of Organizational Commitment on Turnover Intention}

Organizational commitment is the next factor that affects the turnover intention. (Parker \& Kohlmeyer, 2005) defines organizational commitment as the individual's relative strength identification on an organization and its involvement in a particular organization. Three factors are involved in the organization, namely: (1) 
the certainty belief and acceptance of the values and organizational goals; $(2)$ the desire to exert every effort for the sake of the organization; and (3) a strong desire to remain a member of the organization.

Member organizations have a high commitment, the members of the organization are motivated to be responsible with their work so they provides a good work which will lead to job satisfaction. So with job satisfaction they got from the organizations will minimize the level of turnover intentions from the organizations (Biantoro \& Sihombing, 2012). Some previous researchers found the results of the organization's commitment to the turnover intention effect.

The level of employees organizational commitment can affect the turnover intention (Olawale et al., 2016). These results imply if the employees have a strong commitment to the organization, it will affect on the decrease of turnover intention (Meyer et al., 2002; Salleh et al., 2012; Haryokusumo, 2012; Biantoro \& Sihombing, 2012; Jehanzeb et al., 2013; Oktaviani \& Nurhayati, 2014; Saeed et al., 2014; Yasmin \& Marzuki, 2015). Based on previous review studies and explanations, the third hypotheses proposed in this study is:

H3: Organizational Commitment has negative effect on Turnover Intention

\section{The Influence of Leadership Style on Job Satis- faction}

Robbins and Judge (2013) defines job satisfaction as a pleasant emotional state of a person's job ratings. One reason why employees are not satisfied with the job is incompatible with his institutional authority leadership style. When employees feel comfortable with his authority's leadership style it will increase employee job satisfaction. Leadership style is a critical factor that determining employee satisfaction.

Different leadership styles gives direct or indirect impact on employee job satisfaction (Bogler, 2002; Heller et al., 1993; Alshahrani \& Baig, 2016). Research conducted by Fitriany et al. (2011) found that leadership style consideration has positive effect on job satisfaction. If the leader is close to employees, respect to the employees opinion and to communicate openly would increase job satisfaction. Some previous research found the influence of leadership style and organizational commitment to job satisfaction and ultimately led to the turnover intention (Fitriany et al., 2011; Joo \& Ready, 2012; Mehrad \& Fallahi, 2014; Long et al., 2014; Bateh \& Heyliger, 2014; Siddiqui \& Jamil, 2015; Sun et al., 2016). Based on the basis of previous studies review and explanations described earlier, the fourt Hypothesis proposed in this study is:

H4: Leadership Style has positive effect on Job Satisfaction.

\section{The Influence of Organizational Commitment on Job Satisfaction}

Another factor influencing job satisfaction is the organizational commitment. Organizational commitment is the extent to which employees believe and accept the organizational goals, as well as the desire to stay with or leave the company ultimately reflected in absenteeism and employee turnover. If employees have a high commitment to the organization, the employees have confidence in the vision of the organization so they will be satisfied. Several studies have found that organizational commitment influences on employee job satisfaction (Anis et al., 2011; Adekola, 2012). Based previous studies and explanations described earlier, the fifth hypotheses proposed in this study is: H5: Organizational Commitment Positively Effect Job Satisfaction

\section{METHOD}

The population in this study are employees at the consulting offices in Semarang. There are 14 tax consultant offices, 5 management consultant offices and 21 law consultant firms operating in Semarang. the category of population in this research is unidentified population so that the total number of employees is definitely not known. The sample in this study are 
112 respondens using convenience sampling method. The data in this study were obtained by questionnaire. The data collection in this study was obtained by distributing questionnaires directly to the employees who work in consulting offices in Semarang

\section{Variables Operational Definition}

\section{Turnover Intention}

Measured by the instrument developed by Donnelly et al. (2003) consisting of three statements including: actively looking for another job, thinking to get out of work and looking for a new alternative job.

\section{Consideration Leadership Style}

Measured using the instruments developed by Gibson (2012) consisting of 5 items statements include: the leader who is close to an employees, mutual trust between authority and employees, the leader appreciate an employees' idea, an authority appreciate employees'criticism and the leader communicates openly and fair with an employee.

\section{Organizational Comitment}

Measured by the instrument developed by (Mowday et al., 1979). The instrument consists of nine statements such as: employees are willing to work hard for the organization, the organization is a great place, maintain membership in the organization, similarity employee and organization values, proud to be part of the organization, the organization inspires to work well, happy to join the organization, the organization is the best place to work, care for the organization.

\section{Job Satisfaction}

Measured using Job Descriptive Index instruments, which was adopted from the JSS (Job Satisfaction Survey) by Spector (2001) which consists of five statements include: salaries, promotions, benefits, communication and co-workers.

\section{RESULT AND DISCUSSION}

\section{Sample Information}

Based on Table 1 there are $57.1 \%$ of female and $42.9 \%$ male respondents. The next group based on education background showed that the majority of respondents had undergraduate education level with the amount of $69.7 \%$, followed by diploma is $23.2 \%$, graduate is $6 \%$ and doctorate is $2 \%$. Based on years of service it showed that the largest proportion of respondents worked 1-3 years is $63.4 \%$, 4-6 years is $19.6 \%$, $7-10$ years is $13.4 \%$ and $3.6 \%$ who worked more than 10 years.

Table 1. Respondents Profile

\begin{tabular}{lllcc}
\hline Number & Characteristic & Clasification & Number of Respondents & Respondent Percentage \\
\hline 1 & Gender & Female & 64 & 57.1 \\
& & Male & 48 & 42.9 \\
\hline Total & & 112 & $100 \%$ \\
\hline 2. & Level of Education & Diploma & 26 & 23.2 \\
& & UnderGraduate & 78 & 69.7 \\
& & Graduate & 6 & 5.3 \\
& & Doctorate & 2 & 1.8 \\
\hline Total & & 112 & $100 \%$ \\
\hline 3. & Years of Service & 1-3 years & 71 & 63.4 \\
& & 4-6 years & 22 & 19.6 \\
& & $7-10$ years & 15 & 13.4 \\
& & $>10$ years & 4 & 3.6 \\
\hline
\end{tabular}


Ceacilia Srimindarti, et al. / Antecedents of Job Satisfaction and The...

\section{Variable Description}

Based on data processing results, the proportional of respondent answering every variable is, the turnover intentions were 2.92. It means that respondents tend to answer disagree. Respondents tend to not look for another job, do not think of work and not look for alternative new jobs. The average leadership styles variable of 5.40 illustrated that respondents tend to answer agree. Employees agreed that being close to their leader as well as using open communication style was more preferable.The next average organizational commitment variable is 5.11 it means that the employees agreed that the consultant officewas a great place to work and gave a lot of inspiration so they feel comfortable. Job satisfaction variables have an average of 4.07 means that employees tend to answer agree. Employees felt satisfied with the salary, promotions, benefits, communication and co-workers.

\section{Reliability and Validity Test}

The result of validity and reliability test depict on Table 2. Validity test results in Table 2 shows that the turnover intention variable, job satisfaction, organizational commitment and leadership style had $\mathrm{KMO}$ value more than 0.5 so the sampling adequacy were fulfilled. While loading factor shows that all indicators in this study hadmore than 0.4 proportion which means that all question itemsin all instruments being used were valid. Reliability testing results indicate that all Cronbach Alpha score proportion is higher than 0.7 , meaning that all variables in the study were reliable.

\section{Regression Analysis}

The model 1 examine the influence of leadership styles, organizational commitment and job satisfaction on the turnover intention. Table 3 showed that F test sig of 0.000 was less than 0.05 it indicated that the model in this study fit with the data and independent variables consist of job satisfaction, leadership style and organizational commitment influence the turnover intention. Based on the adjusted value $\mathrm{R}$ square, it showed that the ability of job satisfaction, leadership style and organizational commitment could explain the turnover intention at $68.7 \%$, while the remain in results were influenced by other factors not included in the model (Table 3 ).

The test result of hypotheses 1 showed job satisfaction had a direct negative effect on turnover intention by the significant value of 0.031 $(\mathrm{p} \leq 0.05)$ and a marked negative beta value -0.046 . These results showed that when employees felt the various dimensions of the work carried out pleasantly, the turnover intentions

Table 2. Reliability and Validity Test

\begin{tabular}{lcccc}
\hline \multirow{2}{*}{ Variables } & Amount of & & Validity & Reliability \\
\cline { 3 - 5 } & Items & KMO & Loading factor & Cronbach Alpha \\
\hline Turnover Intention (TI) & 3 & 0.712 & $0.766-0.842$ & 0.817 \\
Job Satisfaction (JS) & 5 & 0.770 & $0.614-0.718$ & 0.852 \\
Organizational Commitment (OC) & 5 & 0.727 & $0.734-0.827$ & 0.836 \\
Leadership Style (LS) & 4 & 0.712 & $0.685-0.819$ & 0.833 \\
\hline
\end{tabular}

Table 3. Statistical Result Model 1

\begin{tabular}{llcccc}
\hline \multicolumn{1}{c}{ Variables } & Sig 0.F & Adjusted R & Sig 0.t & Beta & Decision \\
\hline Regression & 0.000 & 0.687 & & & \\
Job Satisfied & & & 0.031 & -0.046 & Accepted \\
Leadership Style & & & 0.024 & -0.003 & Accepted \\
Organizational Commitment & & & 0.008 & -0.038 & Accepted \\
\hline
\end{tabular}


Table 4. Statistical Result Model 2

\begin{tabular}{lccccc}
\hline \multicolumn{1}{c}{ Variable } & Sig. F & Adjusted R $^{2}$ & Sig.t & Beta & Decision \\
\hline Regrestion & 0.000 & 0.416 & & & \\
Leadership Style & & & 0.004 & 0.043 & Accepted \\
Organizational Commitment & & & 0.018 & 0.033 & Accepted \\
\hline
\end{tabular}

decreased. This study found that employees' desire to quit the work could be sourced from employees internal factors accordance with the attribution theory (Fitriany et al., 2011; Mahdi et al., 2012; Sutanto \& Gunawan, 2013; Saeed et al., 2014; Khan \& Aleem, 2014).

Hypothesis 2 testing showed that the leadership style had negative effects to turnover intention directly by the significant value 0.024 $(\mathrm{p} \leq 0.05)$ while the beta value is -0.003 . The results of this study showedwhen employees felt comfortable with the supervisor's leadership style, it would have an impact on turnover intentions decline. These results confirmed successfully the attribution theory which states that the employee's behavior can be sourced from external factors which in this study is represented by the leadership style (Long et al., 2012; Amankwaa \& Tsede, 2015; Puni et al., 2016).

Testing of the Hypothesis 3 showed the organization commitment had negative effect to turnover intention directly by the significant value 0.008 ( $\mathrm{p} \leq 0.05)$ while the beta value was -0.038 . This study showed if employees were committed to the organization, they would maintain membership in the organization and would not be looking for another job. This finding was consistent with the attribution theory which stated that the actions of employees doing the turnover intention could be sourced from employees' internal factors that was organizational commitment (Meyer et al., 2002; Salleh et al., 2012; Biantoro \& Sihombing, 2012; Jehanzeb et al., 2013; Nazenin \& Palupiningdyah, 2014; Saeed et al., 2014; Yasmin \& Marzuki, 2015).

Model 2 examined the effect of leadership style and organizational commitment to job satisfaction. Based on Table 4, it could be seen that the value of $\mathrm{F}$ test sig 0.000 was less than 0.05 . It indicated that the model in this research fit to the data and the independent variable consisted with leadership style and organizational commitment influence on job satisfaction. The adjusted value of $\mathrm{R}$ square shows that the leadership style ability and organizational commitment in explaining job satisfaction is $41.6 \%$, while the remaining were influenced by other factors excluded in the model (Table 4).

The test results of Hypothesis 4 showed a positive effect of leadership style on satisfaction with the significant value $0.004(\mathrm{p} \leq 0.05)$ and beta 0.043 . This finding shows that if employees felt comfortable with his supervisor's leadership style applied will influence in the increase of job satisfaction (Fitriany et al., 2011; Joo \& Ready, 2012; Mehrad \& Fallahi, 2014; Long et al., 2014; Bateh \& Heyliger, 2014; Siddiqui \& Jamil, 2015; Sun et al., 2016).

Testing the Hypothesis 5 shows the organizational commitment has positive effect on job satisfaction with 0,018 significant $(\mathrm{p} \leq 0.05)$ while the beta value of 0.033 . This result shows that if employees had a strong commitment and still wanted to maintain membership in the organization which would increase the job satisfaction. Employees could complete all the work in accordance with the commitments undertaken so they would be more satisfied with their jobs. The findings supported the study by (Anis et al., 2011; Adekola, 2012).

\section{CONCLUSION AND RECOMMENDATION}

Based on the discussion can be concluded that job satisfaction has a negative effect on turnover intention, leadership style has a negative effect on turnover intention, organizational 
commitment has a negative effect on turnover intention, leadership style has a positive influence on job satisfaction and organizational commitment has positive effect to job satisfaction, job satisfaction mediates the effect of leadership style on turnover intention, job satisfaction mediates the influence of the organization commitment to turnover intention.

The theoretical implications related to this research are: job satisfaction, leadership style and organizational commitment have a negatively affected the employees turnover intention those who work at consulting office in Semarang. The further results of the study find that the variables of leadership style and organizational commitment positively affects employees' job satisfaction of those who work at consulting office in Semarang. Based on the results of such research, this study supports the attribution theory, which states that a person's behavior can be caused by internal and external factors. Employee decision to get out or remain the work is influenced by internal factors that are organizational commitment and job satisfaction, while external factors that influence is leadership style. Thus, the results of this study success to confirm the attribution theory.

The findings of this study are expected to be useful for consulting office managers in Semarang, managers should be pay more attention to employee's satisfaction if they do not want to lose them. The manager is also expected to use a close leadership style to the employees and conduct open communication will make employees satisfied with their job so it led the turnover intention decline. Other findings from this study indicate that organizational commitment positively affects the turnover intention. Based on this result, the consultant office manager is expected to always instill the values of the organization to a better employee commitment to decline the turnover intentions.Job satisfaction variable is able to mediate the influence of leadership style and organizational commitment to the turnover intention, therefore it is recommended that managers can improve employee satisfaction towards the declining turnover intention.
Limitations of this study lies in the coefficient of determination is relatively low. Possible causes of these results were being not including all the variables that affect the turnover intention. Therefore, the further study is recommended to add a variable that is influential to the turnover intention such as organizational circumstance, competence, performance and complexity of the task to be giving more complete description on turnover intentions.

\section{REFERENCES}

Adekola, B. 2012. The Impact of Organizational Commitment on Job Satisfaction: a Study of Employees at Nigerian Universities. International Journal Humaniora Resource. Study. 2 (2): 1-17.

Alshahrani, F. M. M \& Baig, L. A. 2016. Effect of Leadership Styles on Job Satisfaction among Critical Care Nurses in Aseer, Saudi Arabia. Journal of the College of Physicians and Surgeons Pakistan. 26 (5): 366-370.

Amankwaa, A \& Tsede, O. A. 2015. Linking Transformational Leadership to Employee Turnover: the Moderating Role of Alternative Job Opportunity. International Journal Bussiness Administration. 6 (4): 19-29.

Anis, A., Rehman, K., Rehman, I. U., Khan, M. A \& Humayoun, A. A. 2011. Impact of Organizational Commitment on Job Satisfaction and Employee Retention in Pharmaceutical Industry. African Journal of Business Management. Vol. 5 (17): 7316-7324.

Bateh, J \& Heyliger, W. 2014. Academic Administrator Leadership Styles and the Impact on Faculty Job Satisfaction. Journal Leadership Education. Summer: 34-49.

Bender, K., Donohue, S. M \& Heywood, J. 2005. Job Satisfaction and Gender Segregation. Oxford Economic Paper. 57 (3): 479-496.

Biantoro, L. C \& Sihombing, R. P. 2012. Pengaruh Komitmen Organisasi terhadap Turnover Intention Melalui Kepuasan Kerja dengan Budaya Organisasi sebagai Variabel Anteseden. Jurnal Akuntansi Bisnis. 11 (21): 61-94.

Bogler, R. 2002. Two profiles of schoolteachers: A Discriminant Analysis of Job Satisfaction. Teaching and Teacher Education. 18: 665-673.

Donnelly, D. P., Bryan, D. O \& Quirin, J. J. 2003. Auditor Acceptance of Dysfunctional Audit 
Behavior: An Explanatory Model Using Auditors' Personal Characteristics. Behavioral Research in Accounting. 15 (4): 87-110.

Fitriany., Gani, L., Siregar, S. V., Marganingsih, A \& Anggraita, V. 2011. Analisis Faktor yang Mempengaruhi Kepuasan Kerja Auditor dan Hubungannya dengan Kinerja dan Keinginan Berpindah Kerja Auditor. Jurnal Akuntansi dan Keuangan Indonesia Volume 8 (2): 171196.

Gangai, K. N \& Agrawal, R. 2014. Job Satisfaction and Organizational Commitment: is It Important for Employee Performance. International Journal of Management Business. 5 (4): 269-278.

Gibson, J. L., Ivancevich, J. M., Donnelly, J. H \& Konopaske, R. 2012. Organizations: Behavior, Structure, Processes, 14th Edition. New York: McGraw-Hill.

Gul, S., Ahmad, B., Rehman, S. U., Shabir, N \& Razzaq, N. 2012. Leadership Styles, Turnover Intentions and the Mediating Role of Organizational Commitment. Information Knowledge Management. 2 (7): 41-51.

Haryokusumo, D. 2015. The Effect of Workplace Spirituality Dimensions on Organizational Commitment with Perceived Organizational Support as Moderating Variable. Jurnal Dinamika Manajemen. 6 (2): 187-202.

Heller, H. W., Clay, R \& Perkins, C. 1993. The relationship between Teacher Job Satisfaction and Principal Leadership Style. Journal of School Leadership. 3 (1): 74-86.

Jehanzeb, K., Rasheed, A \& Rasheed, M. F. 2013. Organizational Commitment and Turnover Intentions: Impact of Employee's Training in Private Sector of Saudi Arabia. International Journal of Business and Management. 8 (8). 79-91.

Joo, B. K \& Ready, K. J. 2012. The Influences of Proactive Personality, Performance Goal Orientation, Organizational Learning Culture and Leader-Member Exchange Quality. Career Development International. 17 (3): 276-295.

Khan, A. H \& Aleem, M. 2014. Impact of Job Satisfaction on Employee Turnover: an Empirical Study of Autonomous Medical Institutions of Pakistan. Journal of International Studies. 7 (1): 122-132.

Long, C. S., Thean, L. Y., Ismail, W. K. W \& Jusoh, A. 2012. Leadership Styles and Employees'
Turnover Intention: Exploratory Study of Academic Staff in a Malaysian College. World Applied Science Journal. 19 (4): 575-581.

Long, C. S., Yusof, W. M. M., Kowang, T. O \& Heng, L. H. 2014. The Impact of Transformational Leadership Style on Job Satisfaction. World Applied Sciences Journal. 29 (1): 117-124.

Mahdi, A. F., Zin, M. Z. M., Nor, M. R. M., Sakat, A. A \& Naim, A. S. A. 2012. The Relationship between Job Satisfaction and Turnover Intention. American Journal of Applied Sciences. 9 (9): 1518-1526.

Mehrad, A \& Fallahi, B. 2014. The Role of Leadership Styles on Staff's Job Satisfaction in Public Organizations. Multidiciplinary Scientific Journal. 24 (5): 27-32.

Meyer, J. P \& Allen, N. J. 1991. A Three-Component Conceptualization of Organizational Commitment. Human Resource Management Review. 1 (1): 61-89.

Meyer, J. P., Stanley, D. J., Herscovitch, L \& Topolnytsky, L. 2002. Affective, Continuance and Normative Commitment to the Organization: a Meta-Analysis of Antecedents, Correlates and Consequences. Journal of Vocational Behavior. 61: 20-52.

Mowday, R. T., Porter, L. W \& Steers, R. M. 1979. The Measurement of Organizational Commitment. Journal of Vocational Behavioral. 14 (2): 224-247.

Nazenin, S \& Palupiningdyah. 2014. Peran Stres Kerja dan Kepuasan Kerja untuk Mengurangi Turnover Intention. Jurnal Dinamika Manajemen. 5 (2): 220-227.

Oktaviani, R. M \& Nurhayati, I. 2014. Pengaruh Komitmen Profesi terhadap Turnover Intentions dengan Kepuasan Kerja Sebagai Variabel Pemediasi (Studi pada Karyawan Kantor Konsultan Pajak Di Semarang). Jurnal Bisnis dan Ekonomi. 21 (1): 83-98.

Olawale, A. R., Folusollesanmi, J \& Olarewaju, A. A. 2016. Job Satisfaction, Turnover Intention and Organizational Commitment. Journal of Management Research. 8 (2): 102-114.

Parker, R.J \& Kohlmeyer, J. M. 2005. Organizational Justice and Turnover in Public Accountant Firms: a Research Note. Accounting, Organization and Society. 30: 357-369.

Puni, A., Agyemang, C. B., Asamoah, E. S. 2016. Leadership Styles, Employee Turnover Intentions and Counterproductive Work Be- 
Ceacilia Srimindarti, et al. / Antecedents of Job Satisfaction and The...

haviours. International Journal of Innovative Research and Development. 5 (1): 1-7.

Robbins, S. P \& Judge, T. A. 2013. Organizational Behavior, 15 edition. New Jersey: Pearson Education.

Saeed, I., Waseem, M., Sikander, S \& Rizwan, M. 2014. The Relationship of Turnover Intention with Job Satisfaction, Job Performance, Leader-Member Exchange, Emotional Intelligence and Organizational Commitment. International Journal of Learning and Development. 4 (2): 242-256.

Salleh, R., Nair, M. S \& Harun, H. 2012. Job Satisfaction, Organizational Commitment and Turnover Intention: a Case Study on Employees of a Retail Company in Malaysia. International Journal of Economics and Management Engineering. 6 (12): 3429-3436.

Sartika, D. 2014. Pengaruh Kepuasan Kerja dan Gaya Kepemimpinan Transformasional terhadap Keinginan Keluar Karyawan dengan Komitmen Organisasi sebagai Variabel Mediasi (Sudi Kasus di CV. Putra Tama Jaya). Management Analysis Journal. 3 (2): 1-11.

Siddiqui, A. A \& Jamil, R. A. 2015. Antecedents of Employees' Turnover Intentions: Evidence from Private Educational Institutions. American Journal Economics Business Administration. 7 (4): 160.165.

Spector, P. E. 1988. Development of the Work Locus of Control Scale. Journal of Occupational and Organizational Psychology. 61 (4): 335340.

Srimindarti, C., Hardiningsih, P., Oktaviani, R. M. 2015. Keahlian Auditor dan Turnover Intention sebagai Mediasi Determinan Kinerja Auditor. Jurnal Akuntansi dan Keuangan Indonesia. 12 (2): 169-187.

Sun, Y., Gergen, E., Avila, M \& Green, M. 2016. Leadership and Job Satisfaction: Implications for Leaders of Accountants. American Journal of Industrial and Business Management. 6: 268275.

Sutanto, E. M \& Gunawan, C. 2013. Kepuasan Kerja, Komitmen Organisasional dan Turnover Intentions. Jurnal Mitra Ekonomi dan Manajemen Bisnis. 4 (1): 76-88.

Wood, J., Wallace, J., Zeffane, R., Schermerhorn, J. R., Hunt, J. G \& Osborn, R. N. 1998. Organizational Behaviour: an Asia-Pacific Perspective. Jacaranda: Wiley Ltd.

Yasmin, K \& Marzuki, N. A. 2015. Impact of Organizational Commitment on Intention to Quit among Psychaitric Nurses: Evidence from Pakistan. International Journal of Learning \& Development. 5 (4): 89-103.

Zhang, Y. 2016. A Review of Employee Turnover Influence Factor and Countermeasure a Review of Employee Turnover Influence Factor and Countermeasure. Journal of Human Resource and Sustainability Studies. 4: 85-91. 